\title{
Bibliographic Note
}

A new critical edition of the Waverley Novels is being prepared by the University of Edinburgh Press. In the meantime, all my references to Scott's novels are to first editions with two exceptions: (1) references to Waverley are to the recent Oxford edition by Claire Lamont (Clarendon, 1981), which is based on the first edition; (2) references to the introductory matter and notes added by Scott for the "Magnum Opus" edition are to the Centenary Edition of Waverley Novels, 25 vols. (Edinburgh: Adam and Charles Black, 1870). For ease of reference, I follow the citation of the volume and page number of the first edition with the chapter as consecutively numbered in most modern editions (e.g., 3:23; chap. 36).

The following is a list of abbreviations used for nineteenthcentury critical reviews:

$\begin{aligned} \text { AjR } & \text { Antijacobin Review } \\ \text { AR } & \text { Annual Review } \\ \text { BC } & \text { British Critic } \\ \text { BM } & \text { Blackwood's Edinburgh Magazine } \\ \text { BR } & \text { British Review } \\ \text { Champ } & \text { Champion } \\ C R & \text { Critical Review } \\ \text { DM } & \text { Dublin Magazine } \\ \text { EcR } & \text { Eclectic Review } \\ \text { EdCIn } & \text { Edinburgh Christian Instructor } \\ \text { EdM } & \text { Edinburgh Magazine (continuation of } \\ & \text { Scots Magazine) } \\ \text { EMR } & \text { Edinburgh Monthly Review }\end{aligned}$


xii Bibliographic Note

$\begin{aligned} \text { ER } & \text { Edinburgh Review } \\ \text { FM } & \text { Fraser's Magazine } \\ \text { GM } & \text { Gentleman's Magazine } \\ \text { LdM } & \text { Lady's Magazine } \\ \text { LM } & \text { London Magazine }\end{aligned}$

Gold's LM London Magazine; and Monthly Critical and Dramatic Review

MM Monthly Magazine

MR Monthly Review

NAR North American Review

NBR North British Review

NMM New Monthly Magazine

NUM New Universal Magazine

QR Quarterly Review

SM Scots Magazine

* Two periodicals of the same name were founded in January 1820 , and I follow John O. Hayden (The Romantic Reviewers, 1802-1824 [London: Routledge, 1969]) in using LM to stand for the more famous of the two, the magazine published by Baldwin to which Hazlitt and others contributed. The lesser known magazine was published by Gold; hence the abbreviation Gold's LM. 
The Achievement of Literary Authority 
